\title{
TSC22D3 wt Allele
}

National Cancer Institute

\section{Source}

National Cancer Institute. TSC22D3 wt Allele. NCI Thesaurus. Code C105564.

Human TSC22D3 wild-type allele is located in the vicinity of Xq22.3 and is approximately $64 \mathrm{~kb}$ in length. This allele, which encodes TSC22 domain family protein 3, is involved in both the transcriptional regulation of apoptotic genes and immunosuppression. 